Original Article

\title{
Recruitment of crustose coralline algae on tiles material for monitoring coral larvae settlement's consolidators at Nature Reserve Pulau Sempu, East Java, Indonesia
}

\author{
Recrutamento de algas coralinas crustosas em azulejos para monitorar consolidadores de \\ assentamentos de larvas de coral na Reserva Natural Pulau Sempu, Java Oriental, Indonésia
}

Guntur $^{\mathrm{a}^{*}}$ (D), O.M. Luthfia,b (D) and M. A. Asadia,b (D)

${ }^{a}$ Department of Marine Science, University of Brawijaya, Jl. Veteran Malang, East Java Indonesia

${ }^{\mathrm{b} R e s e a r c h}$ Group Coastal Resilience and Climate Change - CoRECT,University of Brawijaya, Jl. Veteran Malang, East Java, Indonesia

\begin{abstract}
Crustose coralline algae (Corallinophycideae) are red algae that produced calcium carbonate and are well recognized as foundation species in the epipelagic zone of the marine ecosystem. These algae induced settlement juvenile of coral by released chemical cues from bacterial communities on the surface of their colonies. Their extracellular calcium carbonate also can stabilize reef structure that influencing many invertebrate attaches and growth in the seabed. Crustose coralline algae (CCA) have obtained attention because of their distribution and health compromise to increasing seawater temperature, ocean acidification, and pollutant. As a cryptic species in the ecosystem, the presence of CCA recruit sometimes doesn't have attention, especially on their capability to occupy the empty space. This study aimed to document coverage and number of CCA recruit in two different recruitment tile's material. The highest CCA percentage of the cover was showed inside surface than others surface in all stations. Light intensity and low sedimentation were suggested as a key factor of success of high coverage. Overall, station higher CCA recruits have shown from Tiga Warna. Low sedimentation and protection from aerial exposure became the main reason for it. No significant difference number of CCA recruits between marble and sandstone in this study. Successful CCA recruitment in this study can give a wide picture that natural recruitment of coral and other reef biodiversity in Southern Malang might be will succeed because of the abundance of coralline algae that support their life history stage.
\end{abstract} Keywords: CCA, settlement, recruitment, Pulau Sempu, coral reefs.

\begin{abstract}
Resumo
As algas coralinas crustosas (Corallinophycideae) são algas vermelhas que produzem carbonato de cálcio e são bem reconhecidas como espécies de base na zona epipelágica do ecossistema marinho. Essas algas induziram o assentamento juvenil de coral por meio de estímulos químicos liberados por comunidades bacterianas na superfície de suas colônias. Seu carbonato de cálcio extracelular também pode estabilizar a estrutura do recife que influencia muitos invertebrados anexados e crescimento no fundo do mar. As algas coralinas crustosas (CCA) têm obtido atenção devido à sua distribuição e comprometimento da saúde com o aumento da temperatura da água do mar, acidificação dos oceanos e poluentes. Como uma espécie enigmática no ecossistema, a presença de recrutamento CCA às vezes não recebe atenção, especialmente em sua capacidade de ocupar o espaço vazio. Este estudo teve como objetivo documentar a cobertura e o número de recrutamento de CCA em dois materiais de recrutamento diferentes. A maior porcentagem de CCA da cobertura foi mostrada na superfície interna do que nas outras superfícies em todas as estações. A intensidade da luz e a baixa sedimentação foram sugeridas como um fator-chave para o sucesso da alta cobertura. De modo geral, recrutas de CCA mais graduados mostraram-se em Tiga Warna. A baixa sedimentação e a proteção contra a exposição aérea se tornaram a principal razão para isso. Não houve diferença significativa no número de recrutas CCA entre mármore e arenito neste estudo. O recrutamento bem-sucedido de CCA neste estudo pode dar uma imagem ampla de que o recrutamento natural de corais e outros recifes da biodiversidade no sul de Malang será bem-sucedido por causa da abundância de algas coralinas que sustentam seu estágio de história de vida.
\end{abstract}

Palavras-chave: CCA, assentamento, recrutamento, Pulau Sempu, recifes de coral.

*e-mail: guntur@ub.ac.id

Received: November 25, 2020 - Accepted: February 25, 2021

This is an Open Access article distributed under the terms of the Creative Commons Attribution License, which permits unrestricted use, distribution, and reproduction in any medium, provided the original work is properly cited. 


\section{Introduction}

Crustose coralline algae (CCA) are terms to support the amount of red calcifying algae and nowadays become the most complex community of rhodophytes in seawater environments. These algae are wide range geographical distribution that can be found from low to high latitude and from intertidal to depth area. In alive condition, these algae have pink-reddish color and categories as a marine plant (Phylum: Rhodophyta, Class: Florideophyceae, Subclass: Corallinophycidae, Order: Corallinales, Family: Corallinaceae) that attached on the substrate with rootlike called as holdfast (Littler and Littler, 2013; Nash et al., 2019). In the early description, the CCA divide into generic names because of their morphologies differences, a flat form knowing as Lithophyllum and a branched form as Lithothamnium (Littler and Littler, 2013). McCoy and Kamenos (2015) have a different term for flat and branching form that referred as non-articulate (non-genicular) and articulate (genicular) respectively. Last report the Corallinaceae has 30 genera and more than 500 species (Dean et al., 2015).

CCA is one of the most abundant species to inhabit hard substrates in the shallow marine zone. The success of the wide distribution of CCA is triggered by several factors, for instance, light, temperature, nutrient, current, and depth (Steneck, 1985; Nash and Adey, 2017). High cover of CCA has been confirmed from the marine ecosystem in the world Indonesia (Verheij, 1993), GBR Australia (Dean et al., 2015), Indian Ocean (Caragnano et al., 2014), Mediterranean (Zelli et al., 2020), Japan (Yoshioka et al., 2020), Caribbean (Johnson et al., 2019), Arctic (Williams et al., 2020), New Caledonia (Aeby et al., 2016), and Hawaii (Vermeij et al., 2011). Many researchers revealed that CCA has an important role contributing to reef communities such as cementing process of reef framework against the strong current, wave, and storm. Cementing is important to reduce bio-erosion due to herbivore action and physical erosion of reef to maintains reef complexity. CCA also valuable to coral recruitment as they capability to guide coral planulae to find a suitable substrate for them. Through chemical cues (glycoglycerolipids and polysaccharides) coral planulae induce on the surface of CCA (Tebben et al., 2015). To compete on space among macroalgae, CCA release substance that be agent for antifouling compounds resulted in positive recruitment on coral (Vermeij et al., 2011). They cast their thalli to inhibit macroalgal spores attach to their surface (Keats et al., 1997). The increase of $\mathrm{CO}_{2}$ in the atmosphere leads to global climate change that effects on decreasing $\mathrm{pH}$ of seawater. CCA species will become the first coralline alga affected by lower $\mathrm{pH}$ because they deposited $\mathrm{MgCO}_{3}$, which is about $20 \%$ more solvent than aragonite. In recent work, CCA has become more be considered as a bioindicator of seawater chemistry change (McCoy and Kamenos, 2015; Muth et al., 2020).

Benthic organisms such as coral have a planktonic phase that swimming passively on seawater column while relies on chemical cues for finding suitable substrate to settle. For spawner scleractinian coral fertilization between eggs and sperm will occur in the water column for a few days. Larvae then explore the substrate beneath seawater for several days and if any signal from suitable substrates they will attach to it and metamorphose as single polyps (Harrison and Ward, 2001). The larval settlement of scleractinian coral is triggered by CCA and a thin layer of microbe on the substrate (biofilms). Planula larvae of scleractinian, Goniastrea retiformis and Stylaraea punctata, have a preference on CCA covering substrate (Golbuu and Richmond, 2007). Larvae of Acropora also have been induced by CCA for settlement (Ritson-Williams et al., 2014; Whitman et al., 2020) and in Caribbean CCA also facilitates settlement of Agaricia humilis and 3 species of Acropora of Great Barrier Reef also experience the similar condition. Biofilms have been known as an inducer of coral planulae, for instance, Acropora microphthalma larvae prefer to settle on eight-week-old biofilms while planula of coral Pocillopora damicornis prefers on dense biofilms substrate (Tran and Hadfield, 2011; Siboni et al., 2020).

Tiles are a common use for coral recruitment information and many effects of difference of tile have been widely documented (Kennedy et al., 2017). And less information on tile usage for other benthic organisms such as coralline algae. The information about CCA recruitment is very important to measure reef growth in a certain area and monitor reef health. Knowing the basic biology process of recruitment of CCA will further encourage our perception of other reef engineers such as coral or scleractinian (Jorissen et al., 2020; Mallela et al., 2017). This study aims to record CCA percentage on two different types of tiles and comparing of percentage CCA on different and to know CCA population characteristics using their mean crust size.

\section{Materials and Methods}

\subsection{Site selection}

The study was conducted on the reef flat area of Nature Reserve Pulau Sempu, Malang, East Java, Indonesia ( $8^{\circ} 26^{\prime} 28.18 \mathrm{LS} ; 112^{\circ} 40^{\prime} 58.33 \mathrm{BT}$ ) which focusing on Sempu strait, where almost coral grows well in this location (Rosdianto et al., 2020). Three stations have been decided as the location to deploy of tiles for CCA settlement, two in the adjacent of Pulau Sempu which has a local name as Teluk Semut (08026'20,8" S; 112040'52,5" E) and WaruWaru $\left(8^{\circ} 25^{\prime} 49.57 \mathrm{~S} ; 112^{\circ} 41^{\prime} 33.70 \mathrm{E}\right)$. One station is adjacent to Java Island or $500 \mathrm{~m}$ in front of Teluk Semut, it calls as Tiga Warna ( $8^{\circ} 26^{\prime} 22.48 \mathrm{~S}$; $112^{\circ} 40^{\prime} 39.65 \mathrm{E}$ ) (Figure 1 ). Although these stations are in a marine protected area some limited local tourists still visit these areas for water sport activities. And some fishermen still anchoring their ships for maintaining and park for logistic supply from Pondok Dadap (Sendang Biru) harbor (indicated black dot in Figure 1). According to Luthfi et al. (2015), in a day is about 300 fish-ships passed in this area.

\subsection{CCA settlement tiles}

To monitor the number of CCA settlements in Nature Reserve Pulau Sempu were used different types of settlement plates they were sandstone (Palimanan Stone) and marble stone (Marmo Stone) which each has $10 \times 10 \mathrm{~cm}$ (Figure 2b). In the center of stone tiles was bored using an electric drill 


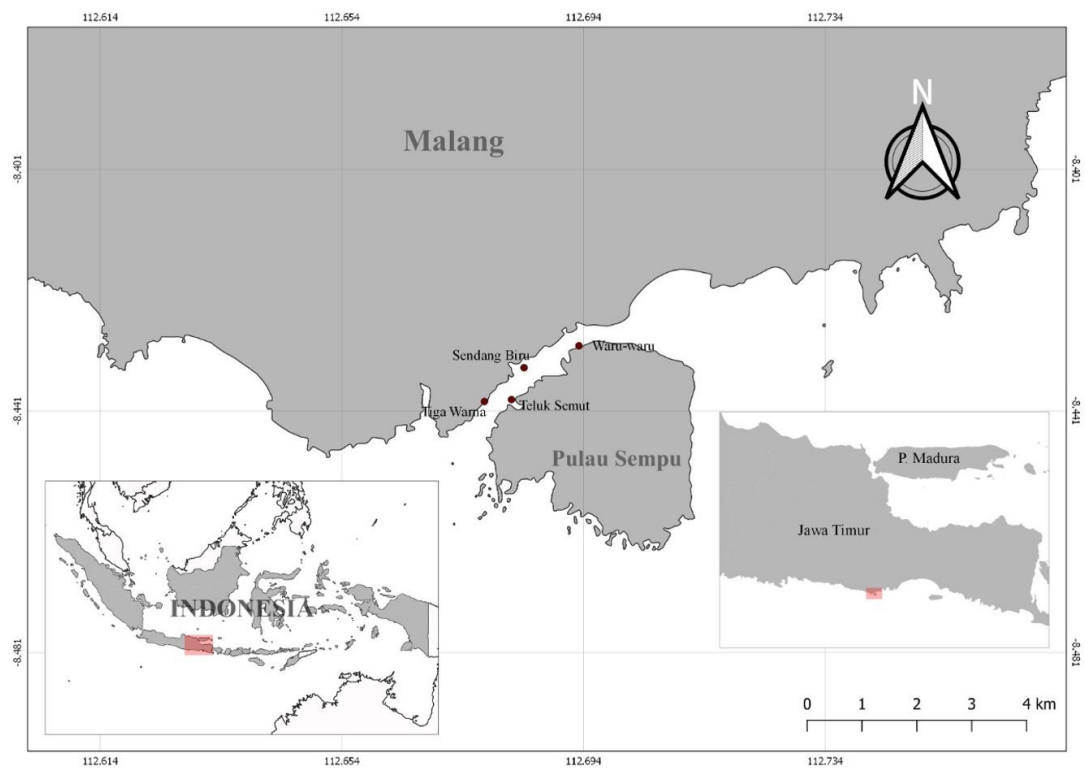

Figure 1. Location of field sites in Natural Reserve Pulau Sempu, Indonesia.
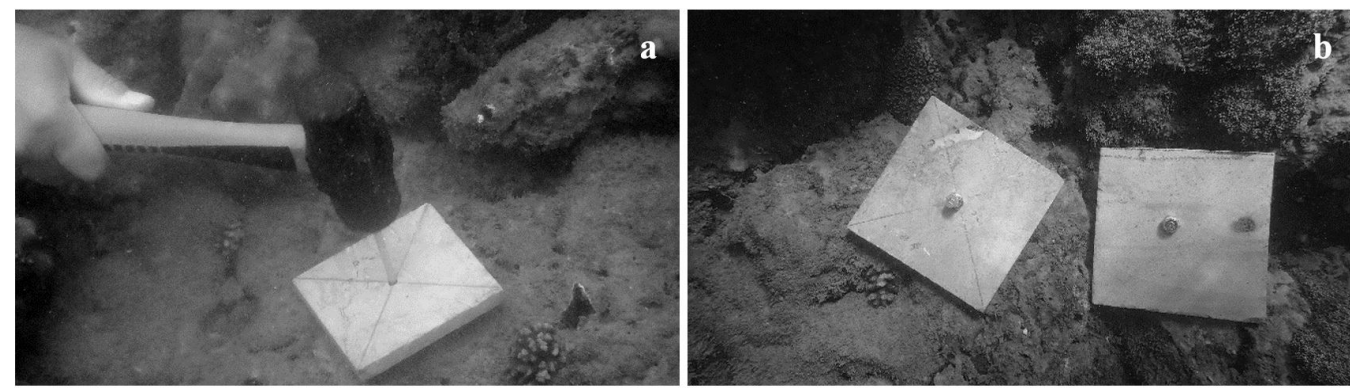

Figure 2. Settlement tiles fixed using $10 \mathrm{~cm}$ stainless nails into a substrate (a) Marmo Stone (MM); (b) Palimanan Stone (PL).

(Bull BL 1811) with drill bit size 10. Through these drilled holes a stainless-steel rod (nail) anchored into hard substratum around of living coral reef by $8 \mathrm{~cm}$ inserted. A nut, size 10 , set between the head of rod and stone made it a space that easier to pull the rode during retrieval. 15 blocks ( 1 block consists of sandstone and marble stone tiles) of CCA settlements anchored in each station which each block separated 1-2 m (Edmunds et al., 2014). All of the blocks were deployed in the middle of July 2020 and retrieved in the middle of October 2020 (3 months). These three months were north east monsoon (dry season) in Java which made sea water very clear due to minimize of river run off from terrestrial and also predicted as main reproductive of reef in this area.

\subsection{Percent cover calculation}

Settlement tiles then dried naturally under the sunlight for two days and photographed on all sides (Figure 3). Each colony of CCA was then delineated and calculated percent cover by ImageJ (NIH, USA) (Reich et al., 2017). The percentage of CCA recruitment cover was calculated as the total area of CCA colonies on all sides of tiles per total area of tiles (Cruz and Harrison, 2017; Oliver et al., 2011). The Formula 1 as below:

$$
C P=\frac{\sum a}{A} 100 \%
$$

Where: $\mathrm{CP}$ is coral cover percentage $\mathrm{A} ; \mathrm{A}=\mathrm{Area}$, and $\boldsymbol{\Sigma} \mathrm{a}$ : total area of CCA's colonies

\subsection{Statistical analysis}

The densities and cover of coral recruits were compared between types of settlement plates. ANOVAs and t-test were used to test the significant difference of types of settlement plates to densities and coverage of CCA. Data were normalized by transforming it using $\log (n+1)$ for fulfilled variance analysis. SPSS ver. 19 was used for statistical analysis of all data (Kennedy et al.).

\section{Results}

\subsection{CCA percent cover}

The mean percentage cover of CCA on Palimanan Stone (PL) at station 1 (Waru-Waru), station 2 (Teluk Semut), and 

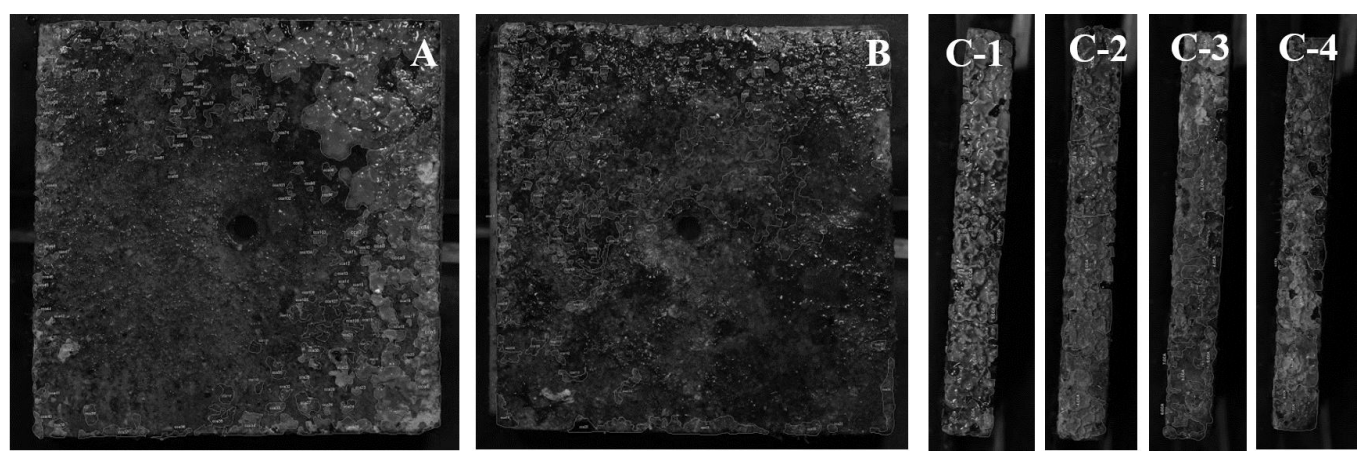

Figure 3. Representation of marble settlement tiles from station Tiga Warna $10 \times 10 \mathrm{~cm}$. (A) upward surface; (B) downward surface; (C)1-4 side surface number 1 to 4 . Coralline algae are seen on delineated yellow lines that cover almost the surface of tiles.

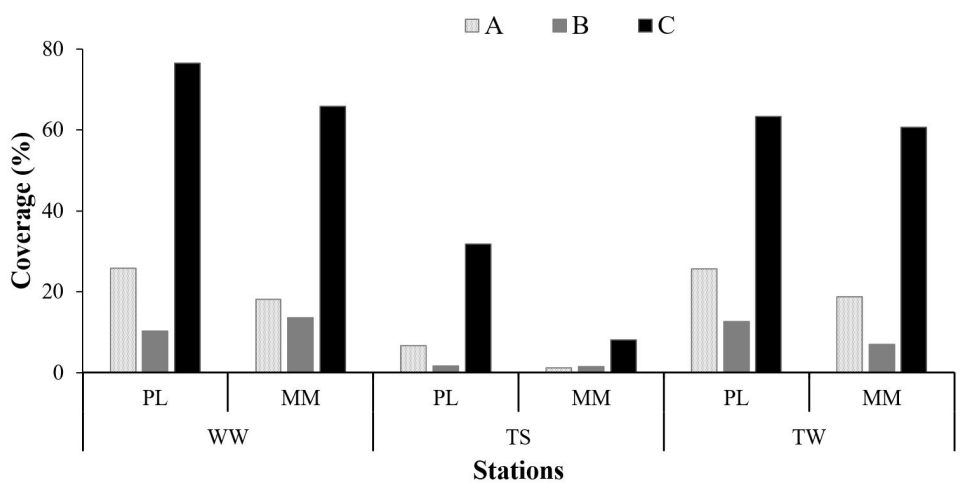

Figure 4. The percentage of CCA settlement cover at all research stations. Most CCA recruits were cover 3 different sides of settlement tiles (A) upward surface; (B) downward surface; (C) sides surface. WW = Waru-Waru; TS = Teluk Semut; TW= Tiga Warna.

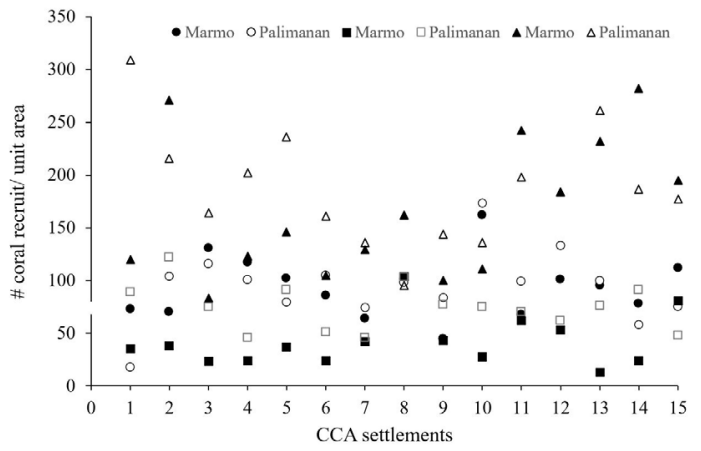

Figure 5. The total number of CCA recruits at all stations, full and blank circle, rectangle, and triangle represent from stations 1,2 , and 3 respectively. The total unit of the surface area is $240 \mathrm{~cm}^{2}$ in each settlement tile.

station 3 (Tiga Warna) were $37.5 \% \pm 20 \mathrm{SE}, 13.4 \% \pm 9.3 \mathrm{SE}$, and $33.8 \% \pm 15.2 \mathrm{SE}$. The coverage on the other stone (Marmo Stone/ MM) was slightly lower $32.5 \% \pm 16.7 \mathrm{SE}$, $3.58 \% \pm 2.3 \mathrm{SE}$, and $28.8 \% \pm 16.3 \mathrm{SE}$ respectively). Overall, the highest trend of CCA coverage was found in Waru-Waru (WW) and the lowest one was found in Teluk Semut (TS) (Figure 4). As resumed in Figure 2, that CCA recruits are attached on all sides of settlement tiles, upward, downward, and side surface. Domination CCA cover of tile sides surface
(C) was found from both of Marmo and Palimanan in all stations (Figure 4). At this side the percent coverage of CCA almost three and six times higher than A and B sides. In average palimanan stone were more attached by algae than marmo stone (Figure 5).

\subsection{Distribution and number of CCA recruit}

The total number CCA recruit adhered at settlement tiles was 9,866 colonies after three months of deployment. The number CCA recruits at Tiga Warna was higher than others, more than half of CCA recruits reported from this station (5,291 colonies) (Table 1$)$. The mean number of CCA recruits per tile was 110 . CCA recruits seemed to have a preference on settlement orientation where upward and side surface were higher occupied by them (Table 1 ). According to of statistical process there was no strong correlation between the number CCA recruits at Palimanan stone and Marmo stone ( $\mathrm{p}$-value $=0.057$ or $\mathrm{p}>0.05$ ).

\section{Discussion}

Calcification on CCA quite different from other invertebrates such as scleractinian coral. In coral, the skeleton consists of aragonite form while in CCA mineralizes magnesium calcite (Nash et al., 2019). Deposit of Mg-Ca was on their cell wall and made their thallus became hard. 
Table 1. Composition and total of CCA recruits in three different orientations (upward, downward, and side stated as A, B, and C respectively) at three stations which $n=15$ block or 30 settlement tile per station. The unit is colony.

\begin{tabular}{|c|c|c|c|c|c|c|c|}
\hline \multirow{2}{*}{ Stations } & \multicolumn{3}{|c|}{ Marmo } & \multicolumn{3}{|c|}{ Palimanan } & \multirow{2}{*}{ Total } \\
\hline & A & B & C & A & B & C & \\
\hline Waru-Waru & 575 & 522 & 308 & 671 & 521 & 225 & 2,822 \\
\hline Teluk Semut & 150 & 79 & 402 & 396 & 128 & 598 & 1,753 \\
\hline Tiga Warna & 734 & 769 & 982 & 749 & 976 & 1081 & 5,291 \\
\hline
\end{tabular}

The red pigment that was called phycobiliproteins caused these species to have red or pink color (Mogstad and Johnsen, 2017). In this study, almost all the CCA recruits had thin and thick thallus. The thin crust was more dominated in all side surfaces of settlement tiles than the thick one. Pneophyllum conicum, for instance, is one of the thin crust of CCA that has a complete reproductive structure in their thallus after 14 days of settlement that causes these species to become dominant species in the southwest Atlantic (Mariath et al., 2013). Abiotic factors such as sedimentation rate also influenced of CCA cover in the new substrate which the result of this study showed that Teluk Semut has more turbid area than Waru-Waru and Tiga Warna. In this case, might be a high sedimentation rate will reduce the growth of CCA. The high accumulation of sediment, more than $10 \mathrm{mg} / \mathrm{cm}^{2} /$ day, can reduce irradiance and inhibit the photosynthesis process of CCA. Furthermore, sediment can cover the surface of CCA and create anoxic condition and decrease the recruitment process (Harrington et al., 2005; Mariath et al., 2013).

The highest coral cover percentage was found from the side surface of settlement tiles and followed by an upward position (Figure 4). CCA is dependent on light, only view of CCA reported growth and distributed limited from the non-euphotic zone. For instance, distribution of the deepest rhodoliths that was found in $295 \mathrm{~m}$ off San Salvador Seamount of Bahama, survive with dim light about $8.10^{-2} \mu \mathrm{mol}$ photons $/ \mathrm{m}^{2} / \mathrm{s}^{1}$, less diverse comparing with high sunlight irradiance in the upper-intertidal area (Littler and Littler, 2013). Photosynthesis is an important process of CCA growth or calcification. Carbon dioxide and bicarbonate uptake from seawater elevate $\mathrm{pH}$ in the internal body of CCA leading to aragonite precipitation in thallus surface (Larkum et al., 2003; Nash et al., 2019). Side and the upward surface was received full of sunlight up to $2,300 \mu \mathrm{mol}$ photons $/ \mathrm{m}^{2} / \mathrm{s}^{1}$ that can ensure of growth rate CCA rapidly (Kim et al., 2013). Furthermore, these positions will receive more nutrients and give a chance CCA faster-growing horizontally along with a rose of fertility (Littler and Littler, 2013).

As all stations are located in the nearshore of coral reef ecosystem, threats such as sedimentation from runoff of rivers also anthropogenic activity. In this study we didn't measure the sediment rate in each location however we suggested that less sedimentation effect on the side surface of settlement tiles increasing the number of CCA recruit survival. 90 degree of shape of side tile to the sea bottom had pulled sediment particle into sea floor because gravity force. Similar to in sessile invertebrates, coral, that smothering sediment can inhibit the photosynthesis process and increasing bacterial infection that allows triggering juvenile mortality (Moeller et al., 2017). Other research also showed that sediment deposition could reduce the number of CCA coverage in New Zealand and GBR (Chew et al., 2013; Harrington et al., 2005). All side of settlement tiles has a 90-degree angle that reduces number sediment on their surface. And the third reason for the high coverage of the side surface of the settlement tile might be because of the influence of mathematics calculation that surface area of each settlement side only $10 \mathrm{~cm}^{2}$, however in upward and downward of settlement tile the area was $100 \mathrm{~cm}^{2}$. As simple mathematic formula stated that the smaller denominator will affect on the high number of results.

After 3 months deployed, CCA settlement tiles were occupied by 9,866 colonies which overlapping each other. In this study, the term of single CCA colony is occupying space by hard substrate from thallus of coralline algae growing laterally margin of the substrate (forming disk-like) which separated with others (McCoy and Kamenos, 2015; Mariath et al., 2013). And because the CCA horizontally growth is very slow around $0-10 \mathrm{~mm} /$ year (McCoy and Kamenos, 2015), and our investigation only conducted on 3 months after deployed so fused and overlapping of CCA has been counted as one colony for simplifying of calculation.

Initially, un-calcified spore released from the reproductive organ of CCA (conceptacles) then attach to substratum used glycosaminoglycans (GAGs) or mucopolysaccharides as a single cell and proliferate forming germinative disk to the certain pattern (Bradassi et al., 2013). Cementation occurred below the thallus (hypobasal) to secure tissue calcification and cell division. The next step was developed by hypothallial filaments and thallus growth. A normal thallus is considered when it had a regular shape which it divisions are followed by a squareangled pattern (Bradassi et al., 2013). The success CCA recruit in Tiga Warna was suggested on the influence of environmental factors. Firstly, all settlement tiles in this location are still immersed in seawater although on the lowest tide condition. CCA being able to survive in most threatened but they straightforwardly bleach when exposed to seawater (Tâmega and Figueiredo, 2019). Others two station, Waru-Waru and Teluk Semut, always exposed during low tide so that number of CCA recruit lower than Tiga Warna. Intertidal is a harsh area not only quick environmental change such as temperature and wave action but also highly competitive of the benthic organism. CCA sometimes needs herbivorous fish to remove epiphytes and other algae competitors from their surface area. Some epiphytes such as seaweed and alga turf 
increasing the stress of CCA by surface cell-layer shedding (Littler and Littler, 2013).

CCA became a secondary reef builder since 150 million years ago and can any colonize any substrate and distributed on wide range habitat, from tropical to the arctic area (Williams et al., 2020; Muth et al., 2020; Halfar et al., 2013). CCA can live in a wide range of light, temperature and carbon dioxide (McCoy and Kamenos, 2015). In this study, we used two types of material that composed settlement tile, marble, and sandstone. The statistical result showed no significant number of coral recruit at both materials. No information from the previous study about the effect different material of CCA settlement attracts CCA recruits. Edmunds et al. (2014) researched several different material types of refugee coral recruitment such as terracotta, plastic, marble, and coral, in the Mediterranean and Pacific area. After 12 months deployed all material fouled by CCA heavily. This flexibility of CCA habitat in line with their key role to bind sand and rubble, fill cracks, reduce reef erosion and consolidate reef that considered as a natural glue to hold coral reef together.

\section{Conclusions}

In summary, habitat selection and recognition of CCA were influenced by several factors such as sediment, light, tides, and pH. Type of settlement materials was no overall effect on crustose coralline algae recruits' preference in this study, it proved by no significance difference number of colonies attached to different settlement tile. Knowing this fact can ensure that CCA coverage in Nature Reserve Pulau Sempu is good and in the future can attract more coral juveniles in this area.

\section{Acknowledgements}

Many thanks to the student, Adrian Rahman Septiandi, Anwan Rachmad Radiansyah, Jessica Elona Beno Tikulla, Muhammad Tio Supratama, Putra Muhammad Abdillah, who helped with deployed and retrieved settlement tiles and delineated thousands of CCA recruits in the laboratory with us. This work was funded by Research and Community Service Universitas Brawijaya, Indonesia through contract number: DIPA-042.01.2.400919/2020.

\section{References}

AEBY, G., TRIBOLLET, A., LASNE, G. and WORK, T., 2016. Assessing threats from coral and crustose Coralline Algae disease on the reefs of New Caledonia. Marine and Freshwater Research, vol. 67, no. 4, pp. 455-465. http://dx.doi.org/10.1071/MF14151.

BRADASSI, F., CUMANI, F., BRESSAN, G. and DUPONT, S.J.M.B., 2013. Early reproductive stages in the crustose Coralline Algae Phymatolithon lenormandii are strongly affected by Mild Ocean acidification. Marine Biology, vol. 160, no. 8, pp. 2261-2269. http://dx.doi.org/10.1007/s00227-013-2260-2.

CARAGNANO, A., BASSO, D., JACOB, D.E., STORZ, D., RODONDI, G., BENZONI, F. and DUTRIEUX, E., 2014. The Coralline Red Algae Lithophyllum kotschyanum $f$. affine as proxy of climate variability in the Yemen Coast, Gulf of Aden (NW Indian Ocean). Geochimica et Cosmochimica Acta, vol. 124, pp. 1-17. http:// dx.doi.org/10.1016/j.gca.2013.09.021.

CHEW, C.A., HEPBURN, C.D. and STEPHENSON, W., 2013. Low-level sedimentation modifies behaviour in juvenile Haliotis iris and may affect their vulnerability to predation. Marine Biology, vol. 160 , no. 5, pp. 1213-1221. http://dx.doi.org/10.1007/ s00227-013-2173-0.

CRUZ, D.W. and HARRISON, P.L., 2017. Enhanced larval supply and recruitment can replenish reef corals on degraded reefs. Scientific Reports, vol. 7, no. 1, pp. 13985. http://dx.doi.org/10.1038/ s41598-017-14546-y. PMid:29070842.

DEAN, A.J., STENECK, R.S., TAGER, D. and PANDOLFI, J.M., 2015. Distribution, abundance and diversity of crustose coralline algae on the Great Barrier Reef. Coral Reefs, vol. 34, no. 2, pp. 581-594. http://dx.doi.org/10.1007/s00338-015-1263-5.

EDMUNDS, P.J., NOZAWA, Y. and VILLANUEVA, R.D., 2014. Refuges modulate coral recruitment in the Caribbean and the Pacific. Journal of Experimental Marine Biology and Ecology, vol. 454, pp. 78-84. http://dx.doi.org/10.1016/j.jembe.2014.02.009.

GOLBUU, Y. and RICHMOND, R.H., 2007. Substratum preferences in Planula Larvae of two species of scleractinian corals, Goniastrea retiformis and Stylaraea punctata. Marine Biology, vol. 152, no. 3, pp. 639-644. http://dx.doi.org/10.1007/s00227-007-0717-x.

HALFAR, J., ADEY, W.H., KRONZ, A., HETZINGER, S., EDINGER, E. and FITZHUGH, W.W., 2013. Arctic sea-ice decline archived by multicentury annual-resolution record from crustose coralline algal proxy. Proceedings of the National Academy of Sciences, vol. 110, no. 49, pp. 19737-19741. http://dx.doi.org/10.1073/ pnas. 1313775110.

HARRINGTON, L., FABRICIUS, K., EAGLESHAM, G. and NEGRI, A., 2005. Synergistic effects of diuron and sedimentation on photosynthesis and survival of crustose Coralline Algae. Marine Pollution Bulletin, vol. 51, no. 1-4, pp. 415-427. http:// dx.doi.org/10.1016/j.marpolbul.2004.10.042. PMid:15757740.

HARRISON, P. and WARD, S., 2001. Elevated levels of nitrogen and phosphorus reduce fertilisation success of gametes from Scleractinian reef corals. Marine Biology, vol. 139, pp. 1057-1068.

JOHNSON, M.D., BRAVO, L.M.R., O'CONNOR, S.E., VARLEY, N.F. and ALTIERI, A.H., 2019. pH variability exacerbates effects of ocean acidification on a Caribbean crustose Coralline Alga. Frontiers in Marine Science, vol. 6, pp. 150. http://dx.doi.org/10.3389/ fmars.2019.00150.

JORISSEN, H., BAUMGARTNER, C., STENECK, R.S. and NUGUES, M.M. 2020. Contrasting effects of crustose Coralline Algae from exposed and subcryptic habitats on coral recruits. Coral Reefs, vol. 39, pp. 1767-1778.

KEATS, D.W., KNIGHT, M.A. and PUESCHEL, C.M., 1997. Antifouling effects of epithallial shedding in three crustose Coralline Algae (Rhodophyta, Coralinales) on a coral reef. Journal of Experimental Marine Biology and Ecology, vol. 213, no. 2, pp. 281-293. http:// dx.doi.org/10.1016/S0022-0981(96)02771-2.

KENNEDY, E.V., ORDOÑEZ, A., LEWIS, B.E. and DIAZ-PULIDO, G., 2017. Comparison of recruitment tile materials for monitoring Coralline Algae responses to a changing climate. Marine Ecology Progress Series, vol. 569, pp. 129-144. http://dx.doi.org/10.3354/ meps12076.

KIM, J.H., LAM, S.M.N. and KIM, K.Y., 2013. Photoacclimation strategies of the temperate Coralline Alga Corallina Officinalis: a perspective on photosynthesis, calcification, photosynthetic pigment contents and growth. Algae - Korean Phycological Society, vol. 28, no. 4, pp. 355-363. http://dx.doi.org/10.4490/ algae.2013.28.4.355. 
LARKUM, A.W.D., KOCH, E.M. and KÜHL, M., 2003. Diffusive boundary layers and photosynthesis of the Epilithic Algal community of coral reefs. Marine Biology, vol. 142, no. 6, pp. 1073-1082. http://dx.doi.org/10.1007/s00227-003-1022-y.

LITTLER, M.M. and LITTLER, D.S., 2013. The Nature of crustose Coralline Algae and their interactions on reefs. Smithsonian Contributions to the Marine, no. 39, pp. 199-212.

LUTHFI, O.M., NURMALASARI, N. and JAUHARI, A., 2015. Growth rate of Staghorn Coral (Acropora) on Coral Garden Program at Sempu nature reserve Malang. Research Journal of Life Science, vol. 2, no. 3, pp. 152-160. http://dx.doi.org/10.21776/ ub.rjls.2016.002.03.2.

MALLELA, J., MILNE, B.C. and MARTINEZ-ESCOBAR, D., 2017. A comparison of epibenthic reef communities settling on commonly used experimental substrates: PVC versus ceramic tiles. Journal of Experimental Marine Biology and Ecology, vol. 486, pp. 290-295. http://dx.doi.org/10.1016/j.jembe.2016.10.028.

MARIATH, R., RODRIGUEZ, R.R. and FIGUEIREDO, M.A., 2013. Succession of Crustose Coralline Red Algae (Rhodophyta) on Coralgal reefs exposed to physical disturbance in the Southwest Atlantic. Helgoland Marine Research, vol. 67, no. 4, pp. 687-696. http://dx.doi.org/10.1007/s10152-013-0354-3.

MCCOY, S.J. and KAMENOS, N.A., 2015. Coralline Algae (Rhodophyta) in a changing world: integrating ecological, physiological, and geochemical responses to global change. Journal of Phycology, vol. 51, no. 1, pp. 6-24. http://dx.doi.org/10.1111/jpy.12262. PMid:26986255.

MOELLER, M., NIETZER, S., SCHILS, T. and SCHUPP, P.J., 2017. Low sediment loads affect survival of coral recruits: the first weeks are crucial. Coral Reefs, vol. 36, no. 1, pp. 39-49. http://dx.doi. org/10.1007/s00338-016-1513-1.

MOGSTAD, A.A. and JOHNSEN, G., 2017. Spectral characteristics of Coralline Algae: a multi-instrumental approach, with emphasis on underwater hyperspectral imaging. Applied Optics, vol. 56, no. 36, pp. 9957-9975. http://dx.doi.org/10.1364/AO.56.009957.

MUTH, A.F., ESBAUGH, A.J. and DUNTON, K.H., 2020. Physiological responses of an arctic crustose Coralline Alga (Leptophytum foecundum) to variations in salinity. Frontiers of Plant Science, vol. 11, pp. 1272. http://dx.doi.org/10.3389/fpls.2020.01272. PMid:32973834.

NASH, M.C. and ADEY, W., 2017. Multiple phases of Mg-calcite in crustose Coralline Algae suggest caution for temperature proxy and ocean acidification assessment: lessons from the ultrastructure and biomineralization in Phymatolithon (Rhodophyta, Corallinales). Journal of Phycology, vol. 53, no. 5, pp. 970-984. http://dx.doi.org/10.1111/jpy.12559. PMid:28671731.

NASH, M.C., DIAZ-PULIDO, G., HARVEY, A.S. and ADEY, W., 2019. Coralline Algal calcification: a morphological and process-based understanding. PLoS One, vol. 14, no. 9, pp. e0221396. http:// dx.doi.org/10.1371/journal.pone.0221396. PMid:31557180.

OLIVER, L.M., LEHRTER, J.C. and FISHER, W.S., 2011. Relating landscape development intensity to coral reef condition in the watersheds of St. Croix, US Virgin Islands. Marine Ecology Progress Series, vol. 427, pp. 293-302. http://dx.doi.org/10.3354/meps09087.

REICH, H.G., ROBERTSON, D.L. and GOODBODY-GRINGLEY, G., 2017. Do the shuffle: changes in Symbiodinium Consortia throughout juvenile coral development. PLoS One, vol. 12, no. 2 , pp. e0171768. http://dx.doi.org/10.1371/journal.pone.0171768. PMid:28182684.
RITSON-WILLIAMS, R., ARNOLD, S.N., PAUL, V.J. and STENECK, R.S., 2014. Larval settlement preferences of Acropora palmata and Montastraea faveolata in response to diverse red Algae. Coral Reefs, vol. 33, no. 1, pp. 59-66. http://dx.doi.org/10.1007/ s00338-013-1113-2.

ROSDIANTO, O.M.L., PEBRIZAYANTI, E., ISDIANTO, A., ASADI, M.A., AFFANDI, M. and PUTRANTO, T.W.C., 2020. Prevalence and incidence of white syndrome in Echinopora lamellosa coral at nature reserve Pulau Sempu, Malang, Indonesia. Ecology. Environmental Conservation, vol. 26, suppl. 1, pp. S179-S185.

SIBONI, N., ABREGO, D., PUILL-STEPHAN, E., KING, W.L., BOURNE, D.G., RAINA, J.B., SEYMOUR, J.R. and HARDER, T., 2020. Crustose Coralline Algae that promote coral larval settlement harbor distinct surface bacterial communities. Coral Reefs, vol. 39, pp. 1703-1713.

STENECK, R.S. 1985. Adaptations of crustose Coralline Algae to herbivory: patterns in space and time. In: D.F. Toomey and M.H. Nitecki, eds. Paleoalgology. Berlin: Springer, pp. 352-366.

TÂMEGA, F.T. and FIGUEIREDO, M.A., 2019. Colonization, growth and productivity of crustose Coralline Algae in sunlit reefs in the Atlantic Southernmost coral reef. Frontiers in Marine Science, vol. 6, pp. 81. http://dx.doi.org/10.3389/fmars.2019.00081.

TEBBEN, J., MOTTI, C.A., SIBONI, N., TAPIOLAS, D.M., NEGRI, A.P., SCHUPP, P.J., KITAMURA, M., HATTA, M., STEINBERG, P.D. and HARDER, T., 2015. Chemical mediation of coral larval settlement by crustose Coralline Algae. Scientific Reports, vol. 5, no. 1, pp. 10803. http://dx.doi.org/10.1038/srep10803. PMid:26042834.

TRAN, C. and HADFIELD, M.G., 2011. Larvae of Pocillopora damicornis (Anthozoa) settle and metamorphose in response to surfacebiofilm bacteria. Marine Ecology Progress Series, vol. 433, pp. 85-96. http://dx.doi.org/10.3354/meps09192.

VERHEIJ, E., 1993. The Genus Sporolithon (Sporolithaceae Fam. Nov., Corallinales, Rhodophyta) from the Spermonde Archipelago, Indonesia. Phycologia, vol. 32, no. 3, pp. 184-196. http://dx.doi. org/10.2216/i0031-8884-32-3-184.1.

VERMEIJ, M.J.A., DAILER, M.L. and SMITH, C.M., 2011. Crustose Coralline Algae can suppress macroalgal growth and recruitment on Hawaiian coral reefs. Marine Ecology Progress Series, vol. 422, pp. 1-7. http://dx.doi.org/10.3354/meps08964.

WHITMAN, T.N., NEGRI, A.P., BOURNE, D.G. and RANDALL, C.J., 2020. Settlement of Larvae from four families of corals in response to a crustose Coralline Alga and its biochemical morphogens. Scientific Reports, vol. 10, no. 1, pp. 16397. http:// dx.doi.org/10.1038/s41598-020-73103-2. PMid:33009428.

WILLIAMS, B., CHAN, P.T., HALFAR, J., HARGAN, K. and ADEY, W. 2020. Arctic crustose Coralline Alga resilient to recent environmental change. Limnology and Oceanography, vol. 66, pp. S246-S258.

YOSHIOKA, S., KATO, A., KOIKE, K., MURASE, N., BABA, M. and LIAO, L.M., 2020. Effects of water temperature, light and nitrate on the growth of sporelings of the non-geniculate Coralline Alga Lithophyllum okamurae (Corallinales, Rhodophyta). Journal of Applied Phycology, vol. 32, no. 3, pp. 1923-1931. http://dx.doi. org/10.1007/s10811-020-02100-9.

ZELLI, E., QUÉRÉ, G., LAGO, N., DI FRANCO, G., COSTANTINI, F., ROSSI, S. and BRAMANTI, L., 2020. Settlement dynamics and recruitment responses of mediterranean gorgonians Larvae to different crustose Coralline Algae species. Journal of Experimental Marine Biology and Ecology, vol. 530-531, pp. 151427. http:// dx.doi.org/10.1016/j.jembe.2020.151427. 